\title{
Effect of Some Biostimulants of Growth, Yield and Berry Quality of King Ruby Grapevines
}

\section{B. E. A. Belal}

Viticulture Department, Horticulture Research Institute, Agricultural Research Centre, Cairo, Egypt.

TIS investigation was conducted for two successive seasons

(2013 \& 2014) in the vineyard of EL-Baramoon experimental farm. Hort. Res. Inst. Mansoura, Dakahlia Governorate, Egypt. The vines were of King Ruby cultivar. The chosen vines were fifteen years old, planted in a clay soil under surface irrigation system, spaced at $2 \times 3 \mathrm{~m}$ apart using spur pruning under bilateral cardon trellis method with supporting by double $\mathrm{T}$ system. The aim of the present study was to investigate and evaluate the effect of addition two sources of soil conditioners and biostimulants such as Humic acid (HA) and Effective micro-organisms (EM) beside control with or without three spraying antioxidants treatments such as (ascorbic acid, citric acid and ascorbic + citric acid) on vegetative growth, leaf mineral content, yield and fruit quality of king Ruby grapevine cultivar. Humic acid and (EM) were used as a soil application at rate $\left(10\right.$ and $20 \mathrm{~cm}^{3} /$ vine $)$, respectively and were added on two equal doses for two times, at growth start and full bloom. Ascorbic acid and citric acid were used as a spraying application at rate $(500 \mathrm{ppm})$ and were sprayed on the vine for three times, at growth start, full bloom and 2 week after fruit set.

The obtained results showed that soil application of (HA) gave the highest values of cluster weight, yield, berry weight, berry length, berry width and vitamin $\mathrm{C}$ as well as the best vegetative growth parameters such as (shoot length and leaf area), leaf chlorophyll content, N, P and $\mathrm{K}$ content in leaf petioles as compared with (EM) application particularly in the first season. While no significant differences between (HA) and (EM) applications on SSC\%, total acidity\%, SSC/acid ratio in berry juice as well as total anthocyanin in berry skin were recorded. Concerning spraying application, it was observed that the treatment of ascorbic acid + citric acid gave the highest results in this respect followed by ascorbic acid and citric acid in descending order. Regarding the interaction between soil and spraying applications, the results indicated that the combination of humic acid + ascorbic acid + citric acid and (EM) + ascorbic acid + citric acid gave the highest values of cluster weight, yield, physical and chemical properties of berries and enhanced vegetative growth parameters, $\mathrm{N}, \mathrm{P}$ and $\mathrm{K}$ content in leaf petioles in comparison with other combinations in both seasons of study.

The best results with regard to yield and fruit quality of king Ruby grapevines were obtained when the vines were supplying with humic 
acid as a soil application with ascorbic + citric acids as a spraying application.

Keywords: Grape, King Ruby, Humic acid, EM, Ascorbic and Citric acid.

Grape (vitis vinifera L.) is one of the most important favorite delicious and popular fruits crops and is considered the first deciduous fruit crop in the total area and production all over the world. In Egypt, grape is the second major fruit crop after citrus.

King Ruby cultivar become one of the most important table grapes both in local and international markets. Small berry size and little coloration were produced during the last several years which were reflected on fruit quality, so the grape grower donated all cultural practices a great attention to improve yield and berry quality. Which applying some soil conditioners and biostimulants such as humic acid (HA) and effective microorganisms (EM) to the soil is very important in agro management due to the beneficial effect on the physical, chemical and biological properties of the soil.

Humic acid (HA) is a principal component of humic substances which are the major organic constituents of the soil. It is produced by biodegradation of dead organic matter. It is not a single acid, rather, it is a heterogeneous mixture of many compounds generally similar chemical properties. It performs varies functions in the soil and on plant growth, one of the functions of (HA) is the promotion of root development (Rengrudkij and Partida, 2003).

The mechanism of (HA) activity in promoting plant growth is not completely known, but several explanations have been proposed by some researchers such as increasing cell membrane permeability, oxygen uptake, chlorophyll density, plant root respiration and photosynthesis, phosphate uptake, and root cell elongation (Turkmen et al ., 2004).

According to (Mayhew, 2004) humic substances have demonstrated the ability to: chelate (bind) soil nutrients, improve nutrient uptake, reduce the need for nitrogen fertilizer, remove toxins from soils, activity of beneficial soil microorganisms, solubilize minerals, improve soil structure and improve water holding capacity. Humic substances are recognized as a key component of soil fertility properties, since it controls chemical and biological properties of the rhizosphere (Trevisan et al., 2009).

Enhancement of plant growth using humic acid has been reported to due to increasing nutrients uptake such as $\mathrm{N}, \mathrm{P}, \mathrm{K}, \mathrm{Ca}, \mathrm{Mg}, \mathrm{Fe}, \mathrm{Zn}$ and $\mathrm{Cu}$ (El-Boray et al., 2013).

Furthermore, application of humic acid improves plant growth, yield and fruit quality (Ferrara \& Brunetti, 2010, Gawad Shaheen et al., 2012, Abd El-Aal et al., 2013 Hamza, 2013 and Mohamed et al., 2014).

Egypt. J. Hort. Vol. 42, No.1 (2015) 
Effective microorganisms (EM) mainly consist of more than 60 selected strains of effective and beneficial microorganisms are considered an important biofertilizer. It is responsible for $\mathrm{N}$ fixation and had higher amounts of nutrients, Vitamin B, hormones and antibiotics (Kannaiyan, 2002).

Using EM can release most essential nutrients from rocks and plants residues in the soil and make them available for fruit crops. It may help in improving crop productivity by increasing the field capacity, promoting soil structure and enhancing metabolic activity of organisms. It also acts as a source of most nutrients for plants (Higa and wididana, 1991).

Furthermore, application of EM enhances the growth, yield and quality of fruits (Sabry et al., 2009, Abd El- Hameed et al., 2010, Ahmed et al., 2011 and Abd El-Aal et al., 2013).

Antioxidants such as ascorbic acid and citric acid have auxinic action and also synergistic effect on flowering and fruiting of fruit trees. Recently antioxidants have been used instead of auxins and other chemical for enhancing growth and fruiting of various fruit trees. Also, are safe to human, environment and used for controlling plant diseases, protecting plant cells from senescence as well as enhancing the biosynthesis of carbohydrates, protein, plant pigments, cell division and cell elongation (Elade, 1992).

Kamiya et al. (1984) stated that "the physiological effects of ascorbic acid included: stimulation of lipase, catalase and peroxides isoenzymes activities". In addition, ascorbic acid revealed an effect on the metabolism of gibberellic acid.

Ascorbic acid as Antioxidants is currently considered plant growth regulator and development owing to its effect on cell division and differentiation. Also, it is involved in wide range of important functions as antioxidant, defense, photo protection, regulation of photosynthesis and growth regulation (Blokhina et al., 2003).

Also, Citric acid produced energy compounds, which is used for metabolism processes and maintenance functions of cells (Jana and Ghosh, 1995).

Pervious studies showed that using antioxidants were beneficial in improving growth, yield and quality of fruits (Fayed, 2010a, Mostafa et al., 2011 and Nerway, 2011).

This investigation was carried out to study and evaluate the effect of humic acid (HA), effective microorganisms (EM) biostimulants and some antioxidants such as ascorbic acid and citric acid on vegetative growth, mineral content in the leaves, yield and fruit quality of King Ruby grapevine cultivar. 


\section{Materials and Methods}

This investigation was carried out during two successive seasons of (2013 \& 2014 ) in the EL-Baramoon experimental vineyard. Hort. Res. Inst. (31 $26^{\prime} 45.6^{\prime \prime}$ E, $\left.31^{\circ} 07^{\prime} 19.2^{\prime \prime} \mathrm{N}\right)$, Mansoura, Dakahlia Governorate, Egypt. The vines were of King Ruby cultivar. The chosen vines were fifteen years old, planted in a clay soil under surface irrigation system, spaced at $2 \times 3 \mathrm{~m}(2 \mathrm{~m}$ within rows and $3 \mathrm{~m}$ between rows) using spur pruning under bilateral cardon trellis method with supporting by double $\mathrm{T}$ system and during the first week of February of each experimental season, the tested vines were spur pruned by leaving 5 spur with 2 eyes on each cordon, the total load was 40 buds per vine. One hundred and eight vines were chosen for this study, such vines were uniform in vigor as possible, all vines received the cultural managements such as fertilization, irrigation, disease and pest control that commonly performed in that district. The experiment consisted of 12 treatments which were arranged in complete randomize blocks design each treatments include three replicates, each contain three vines. The physical and chemical properties of the experimental soil were done according to the method outlined by (Chapman and Pratt 1987) and shown in (Table 1).

TABLE 1. Chemical and physical analysis of the experimental soil .

\begin{tabular}{|l|c|}
\hline Characters & Values \\
\hline Fine Sand \% & 15.63 \\
\hline Coarse sand\% & 4.09 \\
\hline Silt \% & 14.98 \\
\hline Clay \% & 65.30 \\
\hline Texture & Clay \\
\hline pH $(1: 2.5)$ & 7.92 \\
\hline O.M. $\%$ & 1.80 \\
\hline CaCO3 \% & 1.60 \\
\hline E.C. $(1: 5$ extract $)(\mathrm{mmhos} / 1 \mathrm{~cm})$ & 0.88 \\
\hline N $(\mathrm{ppm})$ & 30.60 \\
\hline P $(\mathrm{ppm})$ & 13.75 \\
\hline K $(\mathrm{ppm})$ & 320 \\
\hline
\end{tabular}

Tow sources of conditioners and biostimulants were added to the soil in this study, humic acid (14\%) was used under trade mark (Canada Humex) at rate (10 $\mathrm{cm}^{3} /$ vine) and Effective microorganisms (EM) from Ministry of Agriculture was used at rate $\left(20 \mathrm{~cm}^{3} /\right.$ vine $)$.

Humic acid and (EM) were added on two equal doses for two times, at growth start and full bloom during the two seasons of study beside control treatment (without soil application) in holes around each vine at distance of 50 $\mathrm{cm}$ from the vine trunk and $50 \mathrm{~cm}$ depth.

Egypt. J. Hort. Vol. 42, No.1 (2015) 
The soil application treatments were done with or without three spraying antioxidants treatments at $(500 \mathrm{ppm})$ of either ascorbic acid, citric acid or ascorbic + citric acid beside control treatment (spraying with tap water) on the vine for three times, at growth start, full bloom and 2 week after fruit set. Therefore, the vines were subjected to the following treatments:

1 - Spraying tap water (control)

3 - Spraying Citric acid

5 - Humic acid (HA)

7 - (HA) + Citric acid

9 - Effective microorganisms (EM)

11- $(\mathrm{EM})+$ Citric acid
2 - Spraying Ascorbic acid 4 - Spraying Ascorbic + Citric acid 6 - (HA) + Ascorbic acid $8-(\mathrm{HA})+$ Ascorbic + Citric acid $10-(\mathrm{EM})+$ Ascorbic acid $12-(\mathrm{EM})+$ Ascorbic + Citric acid

\section{Measurements:}

\section{Yield and its components}

Total number of clusters per vine was recorded at harvesting time when SSC $\%$ in berry reached about 16-17 \% in control, six clusters/ vine were weighted and the average cluster weight was multiplied by number of clusters/ vine and hence average yield/ vine was calculated.

\section{Physical properties of cluster and berries}

A sample of 6 clusters/ vine was taken for determining, average cluster weight $(\mathrm{g})$, average berry weight $(\mathrm{g})$, berry length and width $(\mathrm{cm})$.

\section{Chemical properties of berries}

- Soluble solids content (SSC \%) was determined by using a hand refractometer.

- Total acidity percentage was determined according to (A.O.A.C. 1980).

- SSC/acid ratio was calculated by dividing the percentage of SSC on total acidity.

- Total anthocyanin of the berry skin (mg/100g fresh weight) was calculated according to (Husia et al., 1965).

- Vitamin C (mg/100g fresh weight) was determined according to (A.O.A.C. 1980).

Vegetative growth parameters (shoot length and leaf area)

Vegetative growth parameters were determined after two weeks from last treatment (one month after fruit set) as follows:

- Average shoots length $(\mathrm{cm})$.

- Average leaf area $\left(\mathrm{cm}^{2}\right):\left(6^{\text {th }}\right.$ and $7^{\text {th }}$ leaves $)$ from the tip of the growing shoot were used for leaf area measurement according to (Montero et al., 2000).

Chlorophyll content in the leaves: $\left(6^{\text {th }}\right.$ and $\left.7^{\text {th }}\right)$ leaves from the tip of the growing shoots were used for the determination of total chlorophyll content in the leaves after two weeks from last treatment (one month after fruit set) according to (Mackinny, 1941), total chlorophyll was calculated as $\mathrm{mg} / \mathrm{g}$ fresh weight.

\section{$N, P$ and $K$ content in the leaf petiole}

After two week from last treatment (one month after fruit set), $6^{\text {th }}$ and $7^{\text {th }}$ leaves from the tip of the growing shoots were used for the determination of $\mathrm{N}, \mathrm{P}$ and $\mathrm{K}$ content in the leaf petiole according to (Cottenie et al., 1982).

Egypt. J. Hort. Vol. 42, No.1 (2015) 
Statistical Analysis

The complete randomized block design was adopted for the experiment. Duncan's method at 5\% level was used to compare the difference among the treatments average to the methods described by (Waller and Duncan 1969).

\section{Results and Discussion}

Yield and physical properties of cluster and berries

Data in Tables 2 and 3 clearly showed that non-significant differences between the application of humic acid, (EM) and control (without soil application) on number of clusters in both seasons of study. Also, adding humic acid and (EM) significantly increased cluster weight yield/vine, berry weight and berry length and width as compared with control where humic acid treatment recorded the highest values compared with EM treatment.

Concerning the effect of spraying application, data in the same tables indicated that all spraying application gave non-significant difference on number of clusters in both seasons of study. Also, all spraying applications gave the highest significant increase in cluster weight, yield/vine, berry weight and berry length and width as compared with control (spraying with tap water). The spraying of ascorbic acid + citric acid gave the highest values followed by spraying ascorbic acid, citric acid then tap water, respectively in both seasons.

Regarding the effect of interaction between the soil and spraying applications, the data showed non-significant differences on number of clusters in both seasons of study. The combination of humic acid + ascorbic acid + citric acid (A2 x B4) gave the highest significant increase in cluster weight, yield/vine, berry weight, berry length and width as compared with other combinations during the two seasons of study.

These results are in harmony with many investigators such as (Ferrara and Brunetti, 2010) on Italia grape, (Gawad Shaheen et al., 2012) on Crimson seedless and (Hamza, 2013) on King Ruby who worked on humic acid, (Sabry et al., 2009) on Red Glob, (Abd El-Hameed et al., 2010 and Ahmed et al., 2011) on Thompson seedless and (Abd El-Aal et al., 2013) on Superior grapevines who worked on (EM), (Fayed, 2010a) on Thompson seedless who worked on ascorbic and citric acid. They confirmed that the soil application of humic acid and EM and spraying application of ascorbic and citric acid enhanced yield and physical properties of berries.

The positive effect of humic acid on yield and physical properties of berries could be attributed to the enhancing effect on berry weight as a result of enhancing leaf area and total chlorophyll (Table 5). Humic materials lead to increase the permeability of cell plant membranes, promote the uptake of nutrients, photosynthesis, protein synthesis and enzyme activities which promoted the vegetative growth and reflected on the yield. (Chen et al., 2004) Also, (EM) biostimulants contains more than 60 selected strains of

Egypt. J. Hort. Vol. 42, No.1 (2015) 
microorganisms as bacteria, yeast, actinomycetes and various fungi that can be applied through the inoculation to increase the microbial diversity of the soil this in turn can improve soil fertility which lead to enhance the growth, yield and quality of crops (Higa and Kinjo, 1991).

The positive role of antioxidants on the yield and its components could be attributed to auxin action of both ascorbic and critic acid on enhancing cell division and cell enlargement which reflected positively on leaf area and reflected on yield and physical characteristics of berries (Omar, 1999). Also, ascorbic acid revealed an effect on the metabolism of gibberellic acid (Kamiya et al., 1984).

TABLE 2. Effect of Humic acid, EM, Ascorbic acid and Citric acid application on no. of clusters, cluster weight and yield per vine of King Ruby grapevines in 2013 and 2014 seasons .

\begin{tabular}{|c|c|c|c|c|c|c|c|c|}
\hline \multirow{2}{*}{\multicolumn{2}{|c|}{$\overbrace{\text { Treatments }}$}} & \multirow[t]{2}{*}{ Characteristics } & \multicolumn{2}{|c|}{ No. of clusters } & \multicolumn{2}{|c|}{ Cluster weight (g) } & \multicolumn{2}{|c|}{ Yield (kg/vine) } \\
\hline & & & 2013 & 2014 & 2013 & 2014 & 2013 & 2014 \\
\hline \multirow{3}{*}{ 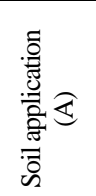 } & \multicolumn{2}{|c|}{ A1 (control) } & $24.42 \mathrm{~A}$ & $24.50 \mathrm{~A}$ & $455.25 \mathrm{C}$ & $464.25 \mathrm{C}$ & $11.12 \mathrm{~B}$ & $11.37 \mathrm{C}$ \\
\hline & \multicolumn{2}{|c|}{ A2 (Humic acid) } & $23.75 \mathrm{~A}$ & $23.83 \mathrm{~A}$ & $525.58 \mathrm{~A}$ & $543.75 \mathrm{~A}$ & $12.47 \mathrm{~A}$ & $12.96 \mathrm{~A}$ \\
\hline & \multicolumn{2}{|c|}{$\mathrm{A} 3 \quad(\mathrm{EM})$} & $24.50 \mathrm{~A}$ & $24.17 \mathrm{~A}$ & $502.75 \mathrm{~B}$ & $522.50 \mathrm{~B}$ & $12.31 \mathrm{~A}$ & $12.64 \mathrm{~B}$ \\
\hline \multirow{4}{*}{ 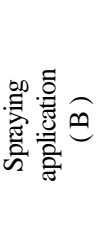 } & \multicolumn{2}{|c|}{ B1 (Tap water) } & $24.22 \mathrm{~A}$ & $23.89 \mathrm{~A}$ & $461.00 \mathrm{D}$ & 474.33D & $11.17 \mathrm{C}$ & $11.32 \mathrm{D}$ \\
\hline & \multicolumn{2}{|c|}{ B2 (Ascorbic acid) } & $24.11 \mathrm{~A}$ & $23.89 \mathrm{~A}$ & 498.78 B & $515.67 \mathrm{~B}$ & $12.03 \mathrm{~B}$ & $12.29 \mathrm{~B}$ \\
\hline & \multicolumn{2}{|c|}{ B3 (Citric acid) } & $24.67 \mathrm{~A}$ & $24.22 \mathrm{~A}$ & $481.33 \mathrm{C}$ & $501.33 \mathrm{C}$ & $11.86 \mathrm{~B}$ & $12.12 \mathrm{C}$ \\
\hline & \multicolumn{2}{|c|}{ B4 (Ascorbic+ Citric) } & $23.89 \mathrm{~A}$ & $24.67 \mathrm{~A}$ & $537.00 \mathrm{~A}$ & $549.33 \mathrm{~A}$ & $12.80 \mathrm{~A}$ & $13.56 \mathrm{~A}$ \\
\hline \multirow{12}{*}{ 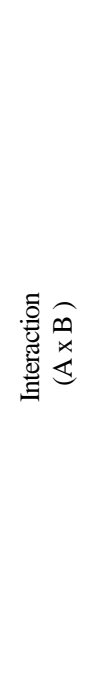 } & \multirow{4}{*}{$\mathrm{A} 1$} & B1 & $24.00 \mathrm{a}$ & $24.33 \mathrm{a}$ & $430.00 \mathrm{~g}$ & $434.00 \mathrm{~g}$ & $10.32 \mathrm{f}$ & $10.56 \mathrm{~h}$ \\
\hline & & $\mathrm{B} 2$ & $24.00 \mathrm{a}$ & $24.67 \mathrm{a}$ & $463.00 \mathrm{f}$ & $464.00 \mathrm{f}$ & $11.11 \mathrm{e}$ & $11.45 \mathrm{~g}$ \\
\hline & & B3 & $25.00 \mathrm{a}$ & $25.00 \mathrm{a}$ & $440.00 \mathrm{~g}$ & $451.00 \mathrm{f}$ & $11.00 \mathrm{e}$ & $11.28 \mathrm{~g}$ \\
\hline & & B4 & $24.67 \mathrm{a}$ & $24.00 \mathrm{a}$ & $488.00 \mathrm{e}$ & $508.00 \mathrm{e}$ & $12.04 \mathrm{c}$ & $12.19 \mathrm{e}$ \\
\hline & \multirow{4}{*}{$\mathrm{A} 2$} & $\mathrm{~B} 1$ & $24.00 \mathrm{a}$ & $24.00 \mathrm{a}$ & $485.00 \mathrm{e}$ & $494.00 \mathrm{e}$ & $11.64 d$ & $11.86 \mathrm{f}$ \\
\hline & & $\mathrm{B} 2$ & $24.00 \mathrm{a}$ & $23.00 \mathrm{a}$ & $525.33 \mathrm{c}$ & $558.00 \mathrm{~b}$ & $12.61 \mathrm{~b}$ & $12.83 \mathrm{c}$ \\
\hline & & B3 & $24.00 \mathrm{a}$ & $23.33 \mathrm{a}$ & $514.00 \mathrm{~cd}$ & $543.00 \mathrm{c}$ & $12.34 \mathrm{bc}$ & $12.67 \mathrm{~cd}$ \\
\hline & & B4 & $23.00 \mathrm{a}$ & $25.00 \mathrm{a}$ & $578.00 \mathrm{a}$ & $580.00 \mathrm{a}$ & $13.29 \mathrm{a}$ & $14.50 \mathrm{a}$ \\
\hline & \multirow{4}{*}{ A3 } & B1 & $24.67 \mathrm{a}$ & $23.33 \mathrm{a}$ & $468.00 \mathrm{f}$ & $495.00 \mathrm{e}$ & $11.55 \mathrm{~d}$ & $11.55 \mathrm{fg}$ \\
\hline & & B2 & $24.33 \mathrm{a}$ & $24.00 \mathrm{a}$ & $508.00 \mathrm{~d}$ & $525.00 \mathrm{~d}$ & $12.36 \mathrm{bc}$ & $12.60 \mathrm{~cd}$ \\
\hline & & B3 & $25.00 \mathrm{a}$ & $24.33 \mathrm{a}$ & $490.00 \mathrm{e}$ & $510.00 \mathrm{e}$ & $12.25 \mathrm{c}$ & $12.41 \mathrm{de}$ \\
\hline & & B4 & $24.00 \mathrm{a}$ & $25.00 \mathrm{a}$ & $545.00 \mathrm{~b}$ & $560.00 \mathrm{~b}$ & $13.08 \mathrm{a}$ & $14.00 \mathrm{~b}$ \\
\hline
\end{tabular}

- In a column, figures having the same letter (s) are not significantly different .

Egypt. J. Hort. Vol. 42, No.1 (2015) 
TABLE 3. Effect of Humic acid, EM, Ascorbic acid and Citric acid application on physical properties of berries of King Ruby grapevines in 2013 and 2014 seasons .

\begin{tabular}{|c|c|c|c|c|c|c|c|c|}
\hline \multirow{2}{*}{\multicolumn{2}{|c|}{ Treatments }} & \multirow{2}{*}{ Characteristics } & \multicolumn{2}{|c|}{$\begin{array}{l}\text { Berry weight } \\
\text { (g) }\end{array}$} & \multicolumn{2}{|c|}{$\begin{array}{l}\text { Berry length } \\
\text { (cm) }\end{array}$} & \multicolumn{2}{|c|}{$\begin{array}{l}\text { Berry width } \\
\quad(\mathrm{cm})\end{array}$} \\
\hline & & & \multirow{2}{*}{$\begin{array}{c}2013 \\
2.87 \mathrm{~B}\end{array}$} & \multirow{2}{*}{$\begin{array}{c}\mathbf{2 0 1 4} \\
2.96 \mathrm{C}\end{array}$} & \multirow{2}{*}{$\begin{array}{c}2013 \\
1.68 \mathrm{~B}\end{array}$} & \multirow{2}{*}{$\begin{array}{c}2013 \\
1.71 \mathrm{C}\end{array}$} & \multirow{2}{*}{$\begin{array}{c}2014 \\
1.39 \mathrm{C}\end{array}$} & \multirow{2}{*}{$\begin{array}{c}\mathbf{2 0 1 3} \\
1.45 \mathrm{C}\end{array}$} \\
\hline & A1 & (control) & & & & & & \\
\hline$\because \frac{\pi}{2}$ & A2 & (Humic acid) & $3.32 \mathrm{~A}$ & $3.44 \mathrm{~A}$ & $1.86 \mathrm{~A}$ & $1.96 \mathrm{~A}$ & $1.55 \mathrm{~A}$ & $1.65 \mathrm{~A}$ \\
\hline$\overline{\overline{0}}$ & \multicolumn{2}{|r|}{ ( EM ) } & $3.23 \mathrm{~A}$ & $3.34 \mathrm{~B}$ & $1.82 \mathrm{~A}$ & $1.88 \mathrm{~B}$ & $1.52 \mathrm{~B}$ & $1.62 \mathrm{~B}$ \\
\hline \multirow{4}{*}{ 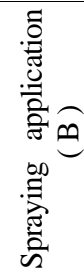 } & \multicolumn{2}{|c|}{ B1 (Tap water) } & $2.90 \mathrm{D}$ & $3.00 \mathrm{D}$ & $1.68 \mathrm{D}$ & $1.74 \mathrm{c}$ & $1.41 \mathrm{D}$ & $1.47 \mathrm{D}$ \\
\hline & \multicolumn{2}{|r|}{ Iscorbic acid) } & $3.18 \mathrm{~B}$ & $3.32 \mathrm{~B}$ & $1.81 \mathrm{~B}$ & $1.84 \mathrm{~B}$ & $1.50 \mathrm{~B}$ & $1.59 \mathrm{~B}$ \\
\hline & \multicolumn{2}{|l|}{ B3 } & $3.05 \mathrm{C}$ & $3.17 \mathrm{C}$ & $1.76 \mathrm{C}$ & $1.81 \mathrm{~B}$ & $1.47 \mathrm{C}$ & $1.56 \mathrm{C}$ \\
\hline & \multicolumn{2}{|c|}{ B4 (Ascorbic+ Citric) } & $3.41 \mathrm{~A}$ & $3.50 \mathrm{~A}$ & $1.89 \mathrm{~A}$ & $1.99 \mathrm{~A}$ & $1.58 \mathrm{~A}$ & $1.67 \mathrm{~A}$ \\
\hline \multirow{12}{*}{ 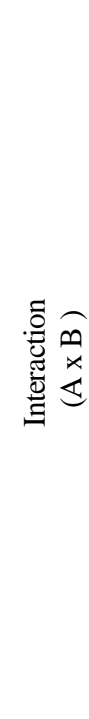 } & \multirow{4}{*}{ A1 } & B1 & $2.68 \mathrm{~h}$ & $2.76 \mathrm{i}$ & $1.57 \mathrm{~g}$ & $1.58 \mathrm{~h}$ & $1.33 \mathrm{i}$ & $1.35 \mathrm{~h}$ \\
\hline & & B2 & $2.88 \mathrm{~g}$ & $2.96 \mathrm{~h}$ & $1.70 \mathrm{ef}$ & $1.73 \mathrm{fg}$ & $1.40 \mathrm{gh}$ & $1.47 \mathrm{~g}$ \\
\hline & & B3 & $2.80 \mathrm{~g}$ & $2.90 \mathrm{~h}$ & $1.67 \mathrm{f}$ & $1.67 \mathrm{~g}$ & $1.37 \mathrm{hi}$ & $1.43 \mathrm{~g}$ \\
\hline & & B4 & $3.10 \mathrm{e}$ & $3.22 \mathrm{ef}$ & $1.77 \mathrm{~d}$ & $1.85 \mathrm{de}$ & $1.47 \mathrm{ef}$ & 1.57 ef \\
\hline & \multirow{4}{*}{ A2 } & B1 & $3.08 \mathrm{e}$ & $3.17 \mathrm{f}$ & $1.73 \mathrm{de}$ & $1.83 \mathrm{de}$ & $1.45 \mathrm{efg}$ & $1.53 \mathrm{f}$ \\
\hline & & B2 & $3.35 \mathrm{c}$ & $3.57 \mathrm{~b}$ & $1.90 \mathrm{~b}$ & $1.97 \mathrm{bc}$ & $1.57 \mathrm{bc}$ & $1.67 \mathrm{bc}$ \\
\hline & & B3 & $3.20 \mathrm{~d}$ & $3.33 \mathrm{~d}$ & $1.83 \mathrm{c}$ & $1.90 \mathrm{~cd}$ & $1.53 \mathrm{~cd}$ & $1.63 \mathrm{~cd}$ \\
\hline & & B4 & $3.64 \mathrm{a}$ & $3.70 \mathrm{a}$ & $1.97 \mathrm{a}$ & $2.13 \mathrm{a}$ & $1.67 \mathrm{a}$ & $1.75 \mathrm{a}$ \\
\hline & \multirow{4}{*}{$A^{3}$} & B1 & $2.94 \mathrm{f}$ & $3.08 \mathrm{~g}$ & $1.73 \mathrm{de}$ & $1.80 \mathrm{ef}$ & $1.43 \mathrm{fg}$ & $1.53 \mathrm{f}$ \\
\hline & & B2 & $3.30 \mathrm{c}$ & $3.43 \mathrm{c}$ & $1.83 \mathrm{c}$ & $1.83 \mathrm{de}$ & $1.53 \mathrm{~cd}$ & $1.63 \mathrm{~cd}$ \\
\hline & & B3 & $3.16 \mathrm{de}$ & $3.27 \mathrm{de}$ & $1.77 \mathrm{~d}$ & $1.87 \mathrm{de}$ & $1.50 \mathrm{de}$ & $1.60 \mathrm{de}$ \\
\hline & & B4 & $3.50 \mathrm{~b}$ & $3.58 \mathrm{~b}$ & $1.93 \mathrm{ab}$ & $2.00 \mathrm{~b}$ & $1.60 \mathrm{~b}$ & $1.70 \mathrm{~b}$ \\
\hline
\end{tabular}

- In a column, figures having the same letter (s) are not significantly different .

Chemical properties of berries

Data illustrated in Table 4 showed that the application of humic acid and EM significantly increased SSC\%, SSC/acid ratio, and total anthocyanin while it is significantly decreased total acidity in berries juice as compared with control. No significant difference between humic acid and (EM) in this respect. Also, the application of humic acid gave the highest values for vitamin $\mathrm{C}$ in berries as compared to EM and control.

Egypt. J. Hort. Vol. 42, No.1 (2015) 


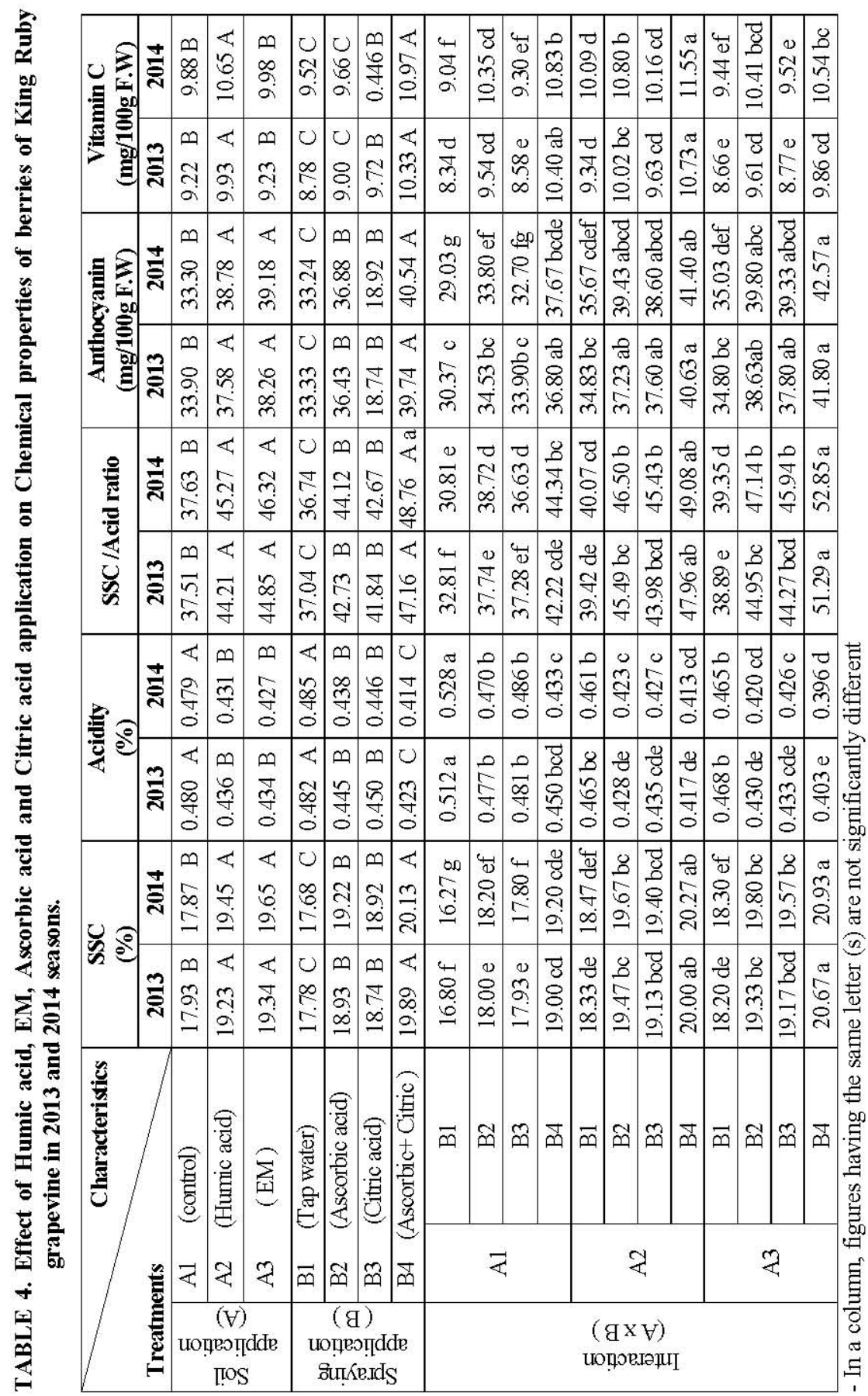


Regarding the effect of spraying application, the data reveled that all treatments gave in both seasons not only the highest significant increase in SSC\%, SSC/acid ratio and total anthocyanin but also the lowest acidity values as compared with (spraying with tap water). The treatments of ascorbic acid + citric acid and ascorbic acid alone gave the highest significant increased on vitamin $\mathrm{C}$ as compared with other treatments.

Concerning the interaction between treatments, the data showed that the combination of humic acid or (EM) with ascorbic acid + citric acid (A2 x B4) and (A3 x B4) gave in both seasons not only the highest values of SSC\%, SSC/acid ratio, and total anthocyanin but also the lowest acidity compared with other combinations. The combination of humic acid + ascorbic acid + citric acid (A2 x B4) was preferable than other combinations in this respect.

The obtain results are in accordance with those reported by (Ferrara and Bruntti, 2010) on Italia grape, (Gawad Shaheen et al., 2012) on Crimson seedless, (El-Shall, 2012) on Strawberry and (Hamza, 2013) on King Ruby who worked on humic acid, (Sabry et al., 2009) on Red Globe, (Abd ElHameed et al., 2010 and Ahmed et al., 2011) on Thompson seedless and (Abd El-Aal et al., 2013) on Superior grapevines who worked on (EM), (Fayed, 2010a) on Thompson seedless and (Fayed, 2010b) on pomegranate trees, who worked on ascorbic and citric acid. They found that humic acid and (EM) applications as well as spraying ascorbic acid and citric acid increased SSC\%, SSC/acid ratio, total anthocyanin, vitamin C and decreased total acidity in berries as compared with control.

The promoting effect of humic acid and (EM) on soil fertility and the availability of most nutrients could result in enhancing the growth, the nutritional status of the vine surely reflected on improving the quality of berries. Also, the enhancement effect of these treatments as a result of ascorbic acid and citric acid may be due to their essential role signal transduction system, membrane stability and function, activating transporter enzymes, metabolism and translocation of carbohydrates (Smirnoff, 1996).

\section{Shoot length, leaf area and leaf chlorophyll content}

Data presented in Table 5 showed that the soil applications of humic acid and (EM) significantly increased shoot length, leaf area and total chlorophyll in leaves as compared with control. The application of humic acid gave the highest significant increase as compared with (EM) application in the first season but in the second season non-significant differences were found between of them. 
EFFECT OF SOME BIOSTIMULANTS OF GROWTH, YIELD AND ...

TABLE 5. Effect of Humic acid, EM, Ascorbic and Citric acid application on shoot length, leaf area and leaf chlorophyll content of King Ruby grapevines in 2013 and 2014 seasons .

\begin{tabular}{|c|c|c|c|c|c|c|c|c|}
\hline \multirow{2}{*}{\multicolumn{3}{|c|}{ Treatments }} & \multicolumn{2}{|c|}{$\begin{array}{l}\text { Shoot length } \\
\text { (cm) }\end{array}$} & \multicolumn{2}{|c|}{$\begin{array}{l}\text { Leaf area } \\
\left(\mathrm{cm}^{2}\right)\end{array}$} & \multicolumn{2}{|c|}{$\begin{array}{c}\text { Total } \\
\text { chlorophyll } \\
\text { (mg|g F.W) }\end{array}$} \\
\hline & & & \multirow{2}{*}{$\begin{array}{c}\mathbf{2 0 1 3} \\
77.42 \mathrm{C}\end{array}$} & \multirow{2}{*}{\begin{tabular}{|c|}
2014 \\
$83.17 \quad B$
\end{tabular}} & \multirow{2}{*}{$\begin{array}{c}\mathbf{2 0 1 3} \\
135.08 \mathrm{C}\end{array}$} & \multirow{2}{*}{$\begin{array}{r}2014 \\
138.67 \mathrm{~B}\end{array}$} & \multirow{2}{*}{$\frac{2013}{2.62 \mathrm{C}}$} & \multirow{2}{*}{$\begin{array}{c}2014 \\
2.65 \mathrm{~B}\end{array}$} \\
\hline 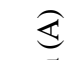 & A1 & (control) & & & & & & \\
\hline \multirow{2}{*}{ 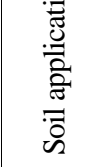 } & A2 & Humic acid) & 95.25 A & $99.42 \mathrm{~A}$ & $150.33 \mathrm{~A}$ & $154.75 \mathrm{~A}$ & $2.99 \mathrm{~A}$ & $3.05 \mathrm{~A}$ \\
\hline & A3 & $(\mathrm{EM})$ & $90.58 \mathrm{~B}$ & $96.67 \mathrm{~A}$ & $146.08 \mathrm{~B}$ & $152.75 \mathrm{~A}$ & $2.88 \mathrm{~B}$ & $3.02 \mathrm{~A}$ \\
\hline \multirow{4}{*}{ 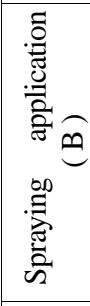 } & B1 & (Tap water) & $77.78 \mathrm{D}$ & $83.22 \mathrm{D}$ & $135.33 \mathrm{D}$ & $139.67 \mathrm{D}$ & $2.65 \mathrm{D}$ & $2.69 \mathrm{D}$ \\
\hline & B2 & Ascorbic acid) & $89.00 \mathrm{~B}$ & $95.11 \mathrm{~B}$ & $145.33 \mathrm{~B} \mathrm{~b}$ & $151.44 \mathrm{~B}$ & $2.87 \mathrm{~B}$ & $2.98 \mathrm{~B}$ \\
\hline & B3 & (Citric acid) & $85.56 \mathrm{C}$ & $90.67 \mathrm{C}$ & $141.67 \mathrm{C}$ & 146.11 C & $2.78 \mathrm{C}$ & $2.85 \mathrm{C}$ \\
\hline & $\begin{array}{l}\text { B4 } \\
\text { Citric }\end{array}$ & Ascorbic + & $98.67 \mathrm{~A}$ & $103.33 \mathrm{~A}$ & $153.00 \mathrm{~A}$ & $157.67 \mathrm{~A}$ & $3.01 \mathrm{~A}$ & $3.09 \mathrm{~A}$ \\
\hline \multirow{12}{*}{ 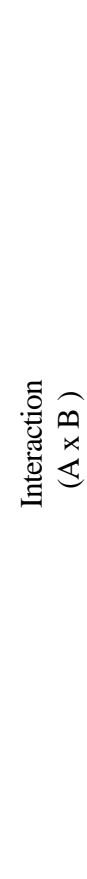 } & \multirow{4}{*}{ A1 } & B1 & $69.67 \mathrm{i}$ & $72.00 \mathrm{~h}$ & $129.00 \mathrm{~h}$ & $130.33 \mathrm{~h}$ & $2.48 \mathrm{~h}$ & $2.50 \mathrm{~g}$ \\
\hline & & B2 & $77.00 \mathrm{gh}$ & $85.67 \mathrm{fg}$ & $135.33 \mathrm{fg}$ & $141.33 \mathrm{fg}$ & $2.63 \mathrm{~g}$ & $2.67 \mathrm{f}$ \\
\hline & & B3 & $75.33 \mathrm{~h}$ & $82.00 \mathrm{~g}$ & $132.00 \mathrm{gh}$ & $136.00 \mathrm{gh}$ & $2.58 \mathrm{~g}$ & $2.61 \mathrm{f}$ \\
\hline & & B4 & $87.67 \mathrm{e}$ & $93.00 \mathrm{cde}$ & $144.00 \mathrm{~cd}$ & 147.00def & $2.78 \mathrm{ef}$ & $2.83 \mathrm{e}$ \\
\hline & \multirow{4}{*}{ A2 } & B1 & $83.67 \mathrm{f}$ & $89.67 \mathrm{def}$ & $140.00 \mathrm{de}$ & 145.33 ef & $2.76 \mathrm{f}$ & $2.80 \mathrm{e}$ \\
\hline & & B2 & $97.00 \mathrm{c}$ & $103.00 \mathrm{~b}$ & $152.67 \mathrm{c}$ & $158.00 \mathrm{ab}$ & $3.09 \mathrm{~b}$ & $3.16 \mathrm{bc}$ \\
\hline & & B3 & $93.33 \mathrm{~d}$ & $94.67 \mathrm{~cd}$ & $148.33 \mathrm{c}$ & $152.00 \mathrm{bcd}$ & $2.94 \mathrm{c}$ & $2.97 \mathrm{~d}$ \\
\hline & & B4 & $107.00 \mathrm{a}$ & $110.3 \mathrm{a}$ & $160.33 \mathrm{a}$ & $163.67 \mathrm{a}$ & $3.18 \mathrm{a}$ & $3.25 \mathrm{a}$ \\
\hline & \multirow{4}{*}{ A3 } & B1 & $80.00 \mathrm{~g}$ & 88.00 ef & $137.00 \mathrm{ef}$ & $143.33 \mathrm{f}$ & $2.71 \mathrm{f}$ & $2.77 \mathrm{e}$ \\
\hline & & B2 & $93.00 \mathrm{~d}$ & $96.67 \mathrm{c}$ & $148.00 \mathrm{c}$ & $155.00 \mathrm{bc}$ & $2.89 \mathrm{~cd}$ & $3.12 \mathrm{c}$ \\
\hline & & B3 & $88.00 \mathrm{e}$ & $95.33 \mathrm{c}$ & $144.67 \mathrm{c}$ & $150.33 \mathrm{cde}$ & $2.83 \mathrm{de}$ & $2.98 \mathrm{~d}$ \\
\hline & & B4 & $101.33 \mathrm{~b}$ & $106.67 \mathrm{ab}$ & $154.67 \mathrm{~b}$ & $162.33 \mathrm{a}$ & $3.08 \mathrm{~b}$ & $3.20 \mathrm{ab}$ \\
\hline
\end{tabular}

- In a column, figures having the same letter (s) are not significantly different . 
Regarding the effect of spraying application, data from the same table clearly showed that spraying application of ascorbic acid + citric acid gave the highest significant increase in shoot length, leaf area and total chlorophyll in leaves followed by single application of ascorbic acid or citric acid and (spraying with tap water) treatment in a descending order.

Concerning the interaction between soil and spraying applications, the combination of humic acid or (EM) with ascorbic acid + citric acid (A2 x B4) and (A3 x B4) gave the highest values in both season of this study when compared with other combinations.

The obtained results are in agreement with findings of (Gawad Shaheen et al., 2012) on Crimson seedless and (Hamza, 2013) on King Ruby, they mentioned that adding humic acid caused increment in shoot length, leaf area and total chlorophyll in leaves. In addition, (Sabry et al., 2009) on Red Globe, (Abd El-Hameed et al., 2010 and Ahmed et al., 2011) on Thompson seedless and (Abd El-Aal et al., 2013) on Superior grapevines, they found that vegetative growth parameters were significantly increased by (EM) applied. Also, (Fayed, 2010a) on Thompson seedless, (Mostafa et al., 2011) on King Ruby and (Nerway, 2011) on Rash-Mew grape, they found that spraying ascorbic acid and citric acid increased shoot length, leaf area and total chlorophyll in leaves.

The beneficial effects of humic acid on vegetative growth have been attributed to improvements in the soil properties and structure and increase photosynthesis, chlorophyll density and plant root respiration which resulted in greater plant growth (Turkmen et al., 2004). Also, (HA) increased microbial population and biologically active metabolites such as plant growth regulators (Trevisan et al., 2009). Also, The enhancement of plant growth by (EM) biostimulants may be attributed to the profound effect of plant growth regulation substance produced by the effective microorganisms (bacteria, yeast and fungi) or in improving the availability and acquisition of nutrients from the soil such as $\mathrm{N}, \mathrm{Mg}$ and $\mathrm{Fe}$ which involved in chlorophyll formation and promoted the vegetative growth (Martin et al., 1989). Also ascorbic and citric acid as antioxidants have many stimulating effects on growth of different plants and activate some physiological processes such as respiration and cell division and elongation which reflected positively on shoot length and leaf area (Blokhina et al., 2003).

\section{$N, P$, and $K$ content in leaf petioles}

The results presented in Table 6 indicated that adding humic acid and (EM) gave positive effect with significant increase in $\mathrm{N}, \mathrm{P}$ and $\mathrm{K}$ in leaf petioles as compared with control in the two seasons of study. No significant difference between the applications of humic acid and (EM) on P content in leaf petioles was observed. $\mathrm{K}$ content in the leaf petioles was significantly increased by the application of humic acid as compared with (EM) during the two seasons of study.

Egypt. J. Hort. Vol. 42, No.1 (2015) 
Concerning the effect of spraying application, the treatment of ascorbic acid + citric acid gave a highest significant increase in N, P and $\mathrm{K}$ during the two seasons of study. Non-significant differences between ascorbic acid and citric acid of N, P and $\mathrm{K}$ content in leaf petioles in the second season were remarked.

In case of effect of interaction, the concerned data showed that the combination of humic acid with spraying ascorbic acid + citric acid (A2 x B4) recorded the highest leaf petioles content of $\mathrm{N}, \mathrm{P}$ and $\mathrm{K}$ followed by the combination of $(\mathrm{EM})+$ ascorbic acid + citric acid (A3 $\times$ B4) as compared with other combinations during the two seasons of study.

The present results are in the same trend with those mentioned by (Gawad Shaheen et al., 2012) on Crimson seedless grapevines and (El-Boray et al., 2013) on King Ruby who worked on humic acid, (Sabry et al., 2009) on Red Globe, (Abd El-Hameed et al., 2010) on Thompson seedless and (Abd El-Aal et al., 2013) on Superior grapevines who worked on (EM), (Fayed, 2010a) on Thompson seedless and (Mostafa et al., 2011) on King Ruby who worked on ascorbic acid and citric acid. They confirmed that the soil application of humic acid and (EM) and spraying application of ascorbic and citric acid enhanced the absorption of macro-elements as they gave the highest values of N, P and $\mathrm{K}$ in leaf petioles as compared with that of control.

The positive effect of humic acid on nutritional status of the leaves may be due to enhancing soil structure, water-air retention capacity, increasing soil microbial population and acts as a buffer solution in cation exchange capacity and $\mathrm{pH}$ ( Magdoff and Weil, 2004). Also, increasing nutrients uptake such as N, $\mathrm{P}$ and $\mathrm{K}$ (El-Boray et al., 2013).

In addition, (EM) biostiumlat improve the availability of nutrients and to the modifications of root growth morphology and/or physiology through hormonal exudates of biofertilizers bacteria are resulting in more efficient absorption of available nutrients (Mohamed et al., 2007). Also, the increase in N, P and K concentration by ascorbic and citric acid may be due to the positive effect on root growth which consequently increase nitrate absorption. Also, may be playing a role in metabolic physiological processes (Fayed, 2010a).

Finally, under condition of the experiment, it can be concluded that using humic acid as a soil application at rate $\left(10 \mathrm{~cm}^{3} /\right.$ vine $)$ in two equal doses for two times at growth start and full bloom with ascorbic acid + citric acid as a spraying application at rate $(500 \mathrm{ppm})$ at growth start, full bloom and 2 week after fruit set had maximized vegetative growth, nutritional status, yield and fruit quality of king Ruby grapevine cultivar. 
TABLE 6. Effect of Humic acid, EM, Ascorbic acid and Citric acid application on N, $P$ and $K \%$ content in the leaf petiole of King Ruby grapevines in 2013 and 2014 seasons .

\begin{tabular}{|c|c|c|c|c|c|c|c|c|}
\hline \multirow{2}{*}{\multicolumn{2}{|c|}{ Treatments }} & \multirow[t]{2}{*}{ Characteristics } & \multicolumn{2}{|c|}{$\mathbf{N} \%$} & \multicolumn{2}{|c|}{ P \% } & \multicolumn{2}{|c|}{ K \% } \\
\hline & & & 2013 & 2014 & 2013 & 2014 & 2013 & 2014 \\
\hline \multirow{3}{*}{ 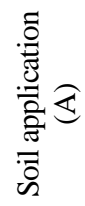 } & A1 & (control) & $2.56 \mathrm{C}$ & $2.60 \mathrm{~B}$ & $0.278 \mathrm{~B}$ & $0.296 \mathrm{~B}$ & $2.20 \mathrm{C}$ & $2.24 \mathrm{C}$ \\
\hline & A2 & (Humic acid) & $2.75 \mathrm{~A}$ & $2.79 \mathrm{~A}$ & $0.389 \mathrm{~A}$ & $0.403 \mathrm{~A}$ & $2.36 \mathrm{~A}$ & $2.44 \mathrm{~A}$ \\
\hline & A3 & ( EM ) & $2.70 \mathrm{~B}$ & $2.76 \mathrm{~A}$ & $0.358 \mathrm{~A}$ & $0.376 \mathrm{~A}$ & $2.28 \mathrm{~B}$ & $2.40 \mathrm{~B}$ \\
\hline \multirow{4}{*}{ 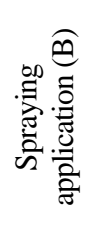 } & B1 & (Tap water) & $2.57 \mathrm{D}$ & $2.62 \mathrm{C}$ & $0.280 \mathrm{C}$ & $0.302 \mathrm{C}$ & $2.18 \mathrm{D}$ & $2.24 \mathrm{C}$ \\
\hline & B2 & (Ascorbic acid) & $2.70 \mathrm{~B}$ & $2.72 \mathrm{~B}$ & $0.347 \mathrm{~B}$ & $0.363 \mathrm{~B}$ & $2.30 \mathrm{~B}$ & $2.39 \mathrm{~B}$ \\
\hline & B3 & (Citric acid) & $2.64 \mathrm{C}$ & $2.69 \mathrm{~B}$ & $0.322 \mathrm{~B}$ & $0.337 \mathrm{BC}$ & $2.26 \mathrm{C}$ & $2.35 \mathrm{~B}$ \\
\hline & B4 & (Ascorbic+ Citric) & $2.76 \mathrm{~A}$ & $2.82 \mathrm{~A}$ & $0.417 \mathrm{~A}$ & $0.430 \mathrm{~A}$ & $2.39 \mathrm{Aa}$ & $2.46 \mathrm{~A}$ \\
\hline \multirow{12}{*}{ 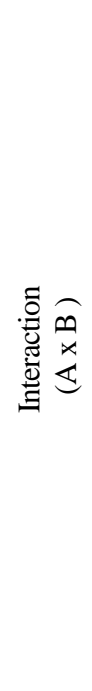 } & \multirow{4}{*}{ A1 } & B1 & $2.47 \mathrm{~h}$ & $2.49 \mathrm{~g}$ & $0.240 \mathrm{~g}$ & $0.233 \mathrm{~g}$ & $2.12 \mathrm{~g}$ & $2.13 \mathrm{i}$ \\
\hline & & B2 & $2.57 \mathrm{~g}$ & $2.61 \mathrm{f}$ & $0.270 \mathrm{fg}$ & $0.310 \mathrm{ef}$ & $2.21 \mathrm{f}$ & $2.26 \mathrm{gh}$ \\
\hline & & B3 & $2.50 \mathrm{~h}$ & $2.57 \mathrm{f}$ & $0.270 \mathrm{fg}$ & $0.280 \mathrm{fg}$ & $2.17 \mathrm{f}$ & $2.24 \mathrm{~h}$ \\
\hline & & B4 & $2.68 \mathrm{ef}$ & 2.73 cde & $0.330 \mathrm{de}$ & 0.360 cde & $2.30 \mathrm{~cd}$ & $2.34 \mathrm{ef}$ \\
\hline & \multirow{4}{*}{$\mathrm{A} 2$} & B1 & $2.65 \mathrm{f}$ & $2.70 \mathrm{de}$ & $0.310 \mathrm{ef}$ & $0.340 \mathrm{de}$ & $2.25 \mathrm{e}$ & $2.31 \mathrm{fg}$ \\
\hline & & $\mathrm{B} 2$ & $2.80 \mathrm{ab}$ & $2.80 \mathrm{bc}$ & $0.400 \mathrm{bc}$ & $0.410 \mathrm{bc}$ & $2.39 \mathrm{~b}$ & $2.48 \mathrm{bc}$ \\
\hline & & B3 & $2.73 \mathrm{~cd}$ & $2.76 \mathrm{~cd}$ & $0.367 \mathrm{~cd}$ & $0.380 \mathrm{~cd}$ & $2.33 \mathrm{c}$ & $2.43 \mathrm{~d}$ \\
\hline & & B4 & $2.83 \mathrm{a}$ & $2.88 \mathrm{a}$ & $0.480 \mathrm{a}$ & $0.480 \mathrm{a}$ & $2.47 \mathrm{a}$ & $2.54 \mathrm{a}$ \\
\hline & \multirow{4}{*}{ A3 } & B1 & $2.60 \mathrm{~g}$ & $2.68 \mathrm{e}$ & $0.290 \mathrm{ef}$ & $0.333 \mathrm{de}$ & $2.17 \mathrm{f}$ & $2.28 \mathrm{gh}$ \\
\hline & & B2 & $2.72 \mathrm{de}$ & $2.76 \mathrm{~cd}$ & $0.370 \mathrm{~cd}$ & $0.370 \mathrm{~cd}$ & $2.30 \mathrm{~cd}$ & $2.43 \mathrm{~d}$ \\
\hline & & B3 & $2.69 \mathrm{def}$ & $2.75 \mathrm{~cd}$ & $0.330 \mathrm{de}$ & $0.350 \mathrm{de}$ & $2.27 \mathrm{de}$ & $2.37 \mathrm{e}$ \\
\hline & & B4 & $2.77 \mathrm{bc}$ & $2.84 \mathrm{ab}$ & $0.440 \mathrm{ab}$ & $0.450 \mathrm{ab}$ & $2.39 \mathrm{~b}$ & $2.51 \mathrm{ab}$ \\
\hline
\end{tabular}

- In a column, figures having the same letter (s) are not significantly different .

\section{References}

A.O.A.C. (1980) "Association of Official Analytical Chemists", $14^{\text {th }}$ ed., published by A.O.A.C., Washington D.C., USA.

Abd El-Aal, A.H.M., Faissal, F.A., Ebrahheim, M.F. and Abd El-Kareem, A.M. (2013) The beneficial effects of some humic acid, EM1 and weed control treatments on fruiting of Superior grapevines. Stem Cell., 4 (3), 25-38 . 
Abd El-Hameed, H.M., Bonok Sawsan A. and Seleem, M.B. (2010) Trial for reducing inorganic $\mathrm{N}$ fertilizer partially by using EM in Thompson seedless vineyard. The sixth Inter. Conf. of Sustain. Agric. and Develop. Fac. of Agric., Fayoum Univ., 27-29 December.

Ahmed, F.F., Ibrahiem, A.A., Mansour, A.E.M., Shaaban, A.F. and El-Shamaa, M.S. (2011) Response of Thompson seedless grapevine to application of some amino acids enriched with nutrients as well as organic and biofertilization. Res. J. Agric. Bio. Sci., 7 (2), $282-286$.

Blokhina, O., Virolainen, E. and Fagerstedt, K.V. (2003) Antioxidants damage and oxygen deprivation stress. Ann. Rev. Bot., 91, 179-194.

Chapman, H.D. and Pratt, P.E. (1987) "Methods of Analysis for Soil, Plant and Water". Univ. California, Div. Agric. Sci., 1, 150.

Chen, Y., De Nobili, M. and Aviad, T. (2004) Stimulatory effects of humic acid on plant growth. In: Soil organic matter in sustainable agriculture (Magdoff F., Weil R. R., eds) CRC Press, NY, USA. pp. 103-129.

Cottenie, A., Verloo, M., Kiekens, L., Relgho, G. and Camerlynuck, W. (1982) Chemical analysis of plant and soil. Lab. of analytical and Agro chemistry State Univ. Gent, Belgium.

Elade, Y. (1992) The use of antioxidants to control grey mould (Botrytis cinera) and white mould (Sclerotionim seletotiorum) in various crops. Plants Path., 141, 417-426.

El-Boray, M.S., Mostafa, M.F. and Ibrahiem, D.M. (2013) Effect of humic acid, Biofertilizers and micro elements on leaf mineral contents of King Ruby seedless grapevines. J. Plant production, Mansoura Univ., 4 (6), 871-883.

El-Shall, Z.S.A. (2012) Partial replacement of inorganic N fertilizer by using humic acid, compost enriched with spirulina platensis algae of strawberry cv. Festival, $J$. plant Production, Mansoura Univ., 3 (5), 925-934.

Fayed, T.A. (2010a) Effect of some Antioxidants on growth, yield and bunch characters of Thompson seedless grapevines. Amer. Eurasian J. Agric. \& Environ. Sci., 8 (3), 322-328.

Fayed, T.A. (2010b) Effect of compost tea and some antioxidants application on leaf chemical constituents, yield and fruit quality of Pomegranate. World J. Agric. Sci., $6(4), 402-411$.

Ferrara, G. and Brunetti, G. ( 2010) Effects of the times of application of a soil humic acid on berry quality of table grape (Vitis vinifera L.) cv. Italia. Spanish J. Agric. Res., 8, 817-822.

Gawad Shaheen, M.A.G., Abd El-Wahab, M., Emad, S.A.H. and Abd El-Aziz, M.R.A. (2012) Effect of some soil conditioners and organic fertilizers on vegetative growth and quality of Crimson seedless grapevines. J. of Hort. Sci. \& Ornamental Plants, 4 (3), 260-266. 
Hamza, D.M. (2013) Physical studies on King Ruby Seedless grapevines Ph.D. Thesis, Fac. of Agric., Mansoura Univ., Egypt.

Higa, T. and Kinjo, S. (1991) Effect of lactic acid fermentation bacteria on plant growth and soil humus formation. pp.140-147. In: parr, S. B. Hornick and C. E. whitman (Ed.) Proc. $1^{\text {st }}$ intl. Conf. on Kyusei Nature Farming Oct.17-21, Khon Kaen Thailand Pub USDA Washigton, D.C.

Higa, Y. and Wididana, G.N. (1991) Changes in the soil micro flora induced by effective microorganisms. pp. 153-162. In J.F. Parr, S. B. Harnick and C.E. Whitman (Ed.) Proc. of the $1^{\text {st }}$ Inter. Conf. of Kyusei Nature Farming M.S. Dept. of Agric., Washington, D.C., U.S.A.

Husia, C.L., Luh, B.S. and Chichester, C.D. (1965) Anthocyanin in free stone peach. $J$. Food Sci., 30, 5-12.

Jana, A. K. and Ghosh, P. (1995) Xanthan biosynthesis in continuous culture: Citric acid as an energy source. J. Ferment Bioeng., 80 (5), 485-491.

Kamiya, Y., Takashi, M., Takahashi, N. and Graebe, J.E. (1984) Conversion of gibberellin A20 to gibberellins A and A5 in cell free system from Phaselus vulgaris. Planta, 162 (2), 152-158.

Kannaiyan, S. (2002) Biotechnology of Bio-fertilizers. Alpha Sci. Inter. Ltd., P.O. Box 4067 Pang Bourne R.G8, UK pp. 1-375.

Mackinny, G. (1941) Absorption of light by chlorophyll soluation. J. Bio. Chem., 140, 315-322.

Magdoff, F. and Weil, R. (2004) Soil organic matter in sustainable agriculture. CRC Press. USA, pp. 67-120, 295-327.

Martin, P.A.W., Glatzle, H.O., Klob, and Shmid, W. (1989) $\mathrm{N}_{2}$ Fixing bacteria in the rizosphere quantification and hormonal effect on root development. Z. Pflonzener nahr bodenk, 152, 237-245.

Mayhew, L. (2004) Humic substances in biological agriculture. Acres, 34 (1\&2).

Mohamed F.M.S., Abd El-Motty, E.Z., El-Shiekh, M.H. and Hagag, L.F. (2007) Effect of some biostimulants on growth and fruiting of Anna apple trees in newly reclaimed area. Res. J. of Agric. \& Biol. Sci., 3 (5), 422-429.

Mohamed, M.A., Ali, A.H., Gobara, A.A. and Abd El-Razek, M.A. (2014) Reducing inorganic N Partially in Superior vineyards by using organic manures enriched with spirulina plantensis Algae. Stem Cell, 5 (3), 16-21.

Montero, F.J., De Juan, J.A., Cuesta, A. and Brasa, A. (2000) Non-destructive methods to estimated leaf area in (Vitis vinifera L.) Hort. Sci., 35, 696-698.

Mostafa, M.F.M., El-Baz, E.E.T., Abd El-Wahab, A.F. and Saeed, A.M.O. (2011) Using different sources of compost tea on grapes. J. Plant production, Mansoura Univ., 2 (7), 935-947.

Egypt. J. Hort. Vol. 42, No.1 (2015) 
EFFECT OF SOME BIOSTIMULANTS OF GROWTH, YIELD AND ...

Nerway, H.M.S. (2011) Effect of foliar sparing of some organic fertilizers on growth, yield and quality of grape cv. Rash-Mew (Vitis vinifera L.) under non irrigated condition, M.Sc. Thesis, Duhok Univ., Irak Kurdstan region.

Omar, A.Kh. (1999) Response of Red Roomy grapevines (Vitis vinifera L.) to some antioxidants and biofertilizer treatments. M.Sc. Thesis, Fac. of Agric. Minia Univ., Egypt.

Rengrudkij, Ph. and Partida, G.J. (2003) The effects of humic acid and phosphoric acid on grafted Hass avocado on Mexican seedling rootstocks. Actas V Congreso Mundial del Aguacate, pp. 395-400.

Sabry, G.H., Rizk-Alla, M. S. and Abd El-Wahab, M.A. (2009) Influence of effective micro-organisms, seaweed extract and amino acids application on growth, yield and berry quality of Red Globe grapevines. J. Agric. Sci. Mansoura Univ., 34 (6), 6617 6637.

Smirnoff, N. (1996) The function and metabolism of ascorbic acid. Plants. Ann. Bot., 78 661-669.

Trevisan, S., Pizzeghello, D., Ruperti, B., Francioso, O., Sassi, A., Palme, K., Quaggiotti, S. and Nardi, S. (2009) Humic substances induce lateral root formation and expression of the early auxin-responsive IAA 19 gene and DR5 synthetic element in Arabidopsis. Plant Biol., 12, 604-614.

Turkmen, O., Dursun, A., Turan, M. and Erdinc, C. (2004) Calcium and humic acid affect seed germination, growth and nutrient content of tomato (Lycopersicon esculentum L.) seedlings under saline soil condition. Acta Agriculturae Scandinavica Section B-Plant Soil Sci., 54 (3),168-174.

Waller, R.A. and Duncan, D.B. (1969) A bays rule for the symmetric multiple comparison problem. J. Amer. Assoc., 64, 1484-1503.

(Received 10/9/2014 accepted $12 / 1 / 2015$ 


$$
\begin{aligned}
& \text { تأثير بعض المنشطاث الحيوية على النمو والمحصول وصفات } \\
& \text { الجودة فى العنب كنج روبى لئي } \\
& \text { بسام السيد عبد المقصود بلال } \\
& \text { قسم بحوث العنب ـ معهذ بحوث البساتين ـ مركز البحوث الزر اعية ـ القاهرة ـ }
\end{aligned}
$$

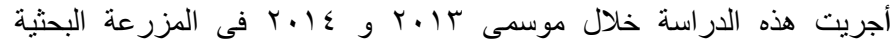

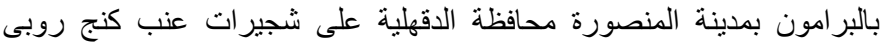

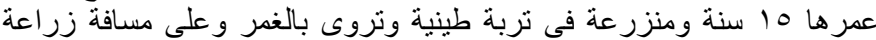

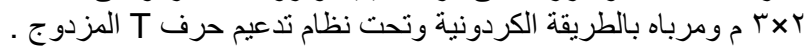

وقد استهدف هذا البحث دراسة نأثير اضافة مصدرين من منشطات التربة مثل الته

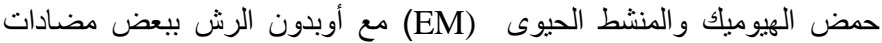

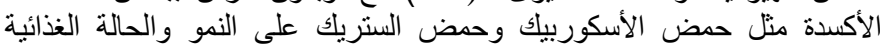
للشجير ات و المحصول وصفات الجودة فى الثمارلصنف العنب كنج العن روبى.

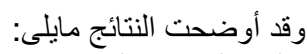

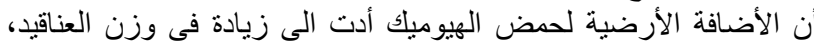

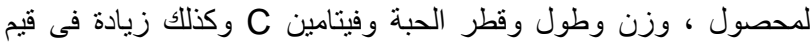

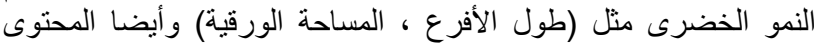

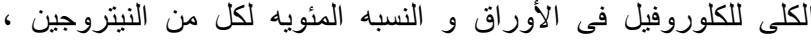

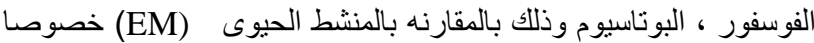

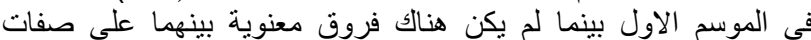

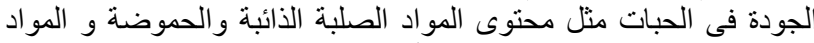
الصلبة الذائبة / الحموضة ودئ وصنوبة الأنثوسيانين.

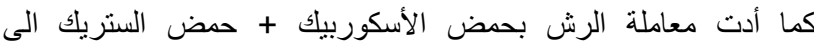

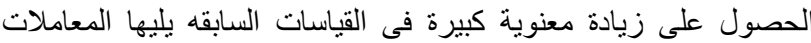

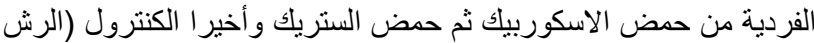

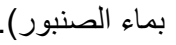

بالنسبه للتداخل بين المعاملات الأرضية و الرش الورقى فقد أعطت معاملـة

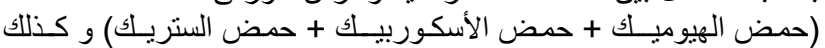

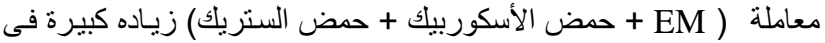
جميع قيم القياسات السابقة خلال موسمى الدر اسه مقارنه بياقى المعاملات.

وكانت أفضل النتائج المتحصل عليها المعاملة (حمض الهيوميك + حمض الأسكوربيك + حضل النيل الستريك).

ولذلك لتحسين صفات الجودة للعناقيد وزيادة المحصول يوصى باستخدام

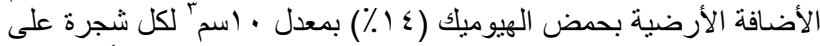

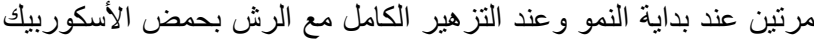

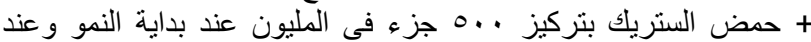
التز هير الكامل وبعد العقد باسبو عين. 